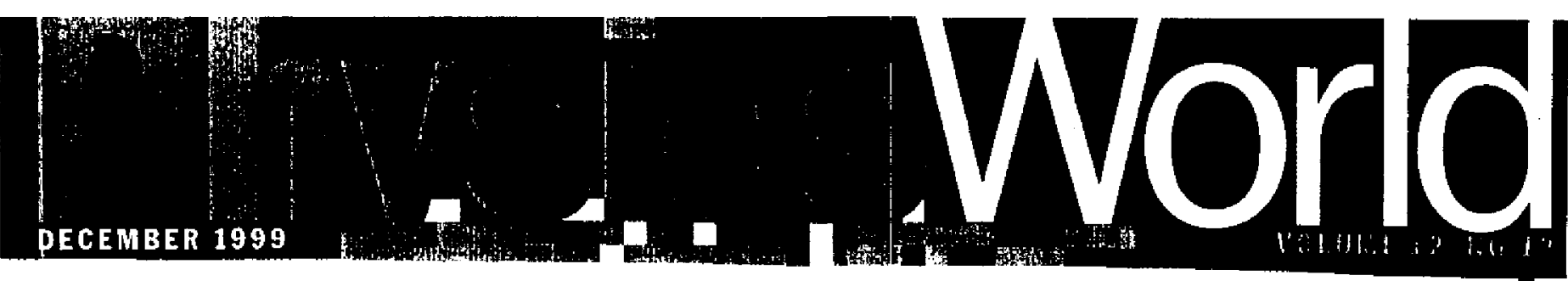

\title{
Physicists must learn to love the public
}

\section{Most physicists now realize the importance of "the public understanding of science", but as Matim Durrani finds out, it is just as vital for scientists to understand the public}

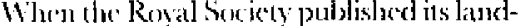

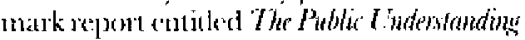
of Sitence in 1985, in was a delinily mement

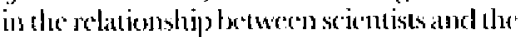
puble in the LK. 'The report argued that sciube is cruedal to the economic, politicat and culiurad life of an advanced industrial

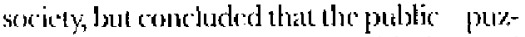
zlingly dots not appreciate this liue and that many people are scemingly igneraton of the role of seisuce.

The socjety proposed a number of ways of bousting the pulslices und restandinge and awarencss of wionec, induding greater cow erage of science in the nedtia ind reforms to the education system. I'he report also led to the birth of something of a coltage industry of hands-on exhibitions, public lectures, laboratory open days and other publicunderstanding initiatives. Even the UK's rescarch councils are now required to pronote the public understanding of se ience.

But the views enshrined in the Royal Society report are now rhallenged by many sociolopists of scienes. "They're misguided," says Harry Gollins of Cardiff University. "l'hey're based on the idea that you can get the public to agrec with seientists on the: conscnsus view of various sciemlific issues simply by giving them the facts. But you won't get cveryone to lowe scienec just by teaching them more seie:lect,"

The problem is that nosit publix-understanding initiatives tend to pecsent science in atl unrealistic lasthion, with se ientists as in[allible creatures on the path to certatio truts. Srienes is depicted as a coluerent loxdy of knowledge with no unertan edges even when most scientists will admit that this is rarely this calse. Indered, some scicness like weather lorecasting and fucoy lengic ase, at their roots, umpredictable.

"Portraying science in this unrealistic way just creates unrealistic expectations that fued "anti-scientific" reactions whet those expectations are not me," explairs Collins. "If" scientists are just trying to glorify secience like. that, then jo ste wrong sort of thing to be doing The glorification of sciene'te is ate terally goitg on harm science in the long torm by raising expectatiots of what scionce can do bo uncatistic lacels."

So if scientists must lot simply prowide the pulblic with "the right exchnical intormaLion", then what sloould they do?" "What 1 think tho public necds to kuow is the soienufic method", says Bruce l awenstem in the clepattencent of commenteation an Comedl

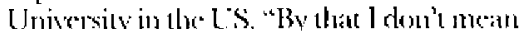

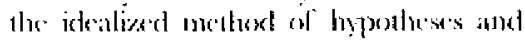

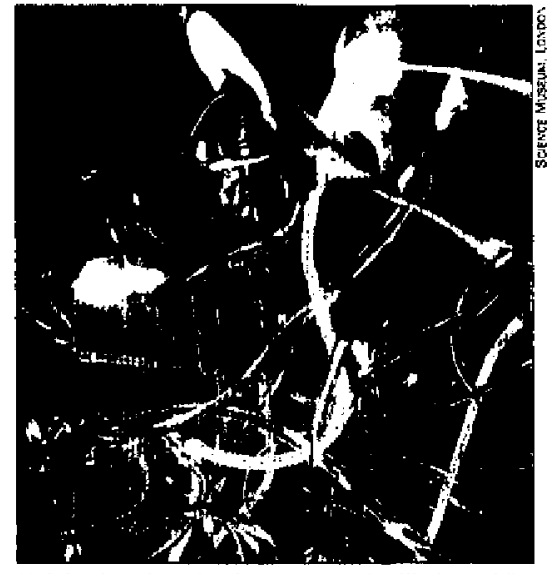

Helping hand - scientists must work with the public

testing, but rather the real messiness of bow we come to have reliable knowledge of the natural world."

"I"rin nel a relativist," continues I cwenstein, "lout it is clear that issues of funding shape: llit questions we ask alyout nature, that pretslems of interpretation and rbetoric shaje: the answers we arcept about the meating of investigations, and that communication is a lundamental part of how raw data get tur ned into intelligible knowledge."

lowenstein, who is editor of the journal

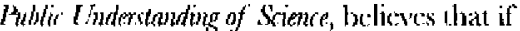
ule pulsic: had a beuter understanding of these contingencies in scientific knowledge, they could make informed choices abo tat sci entilic issues. "1 he putjlie woukd then under stand why sciontists cannot provide "the" answer to various questions," he explaiss.

So what can scicontists do at a practical lovel: "fictentists need to be candid about what is and isn't known," says fohn Duran: professor in the puldic understanding of scirnoce at Imperial College londom. "I'n not satying they should just present science as a sctics of ecpually valid views, bat they should place more emphasis on uncertainty where? it cxists. 'They should remember that while scientific knowledere is reliables, it is not ahvays cortain and complate"

Durant also warns that if scicntists fail in acknowledge the pulslic.s concerns al wou sientilie jsstess, puthic polic y can move too far alyed of public opinjon. "The result, as wo: frate secn with the hestile reate tion fo ge netically modified loods, cat be disist rous" he: wys. "But if sciontists and policy-makers can understand the public loester, the public will in turu platemente toust in scientists and haves

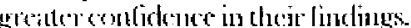

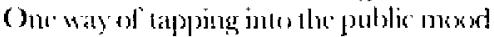

is though "comsensus conferences", in which infinened members of the public examine contmorersial issues and feed their views to policy-makers. Indeed, David lidgre, a sociologist at Fidinlurgh University, belicves that such mechanisms should bc an integral par of the political process. "The only effective way of improving the public's atlitude to sci ence is to have anore open, flexilule and constructive discourse, and non to polarize the debate between experts and laypeople," he says. "Only by having more such democratic fora will scientists maintain their trust and status with the public. If the public accepts consensus conferences as serious attempts to influence policy, peoplc will sec the point of learning about science so that they can participate. Changes in the public's understanding of science will then fotlow.

However, Fdge thinks it is a mistake to blame the public's attitude to science on the media, who are only reflecting public opinion. Steve Connor, science editor of The Independent, explains. "Newspapers aren't public-rclations outfits for science. Our role is not to further the cause of science, but to explain it, and if necessary to point out where there: is bad science even if j1's embarrasing for the scientists involved. Public understanding is a laudable aim, but if there's any naivety on the part of scientists it's the idca that science is always gond."

Arnold Wolfendale, president of the European Physical Socjety, agrees that it is unwisc to blame the media. "Scientists should just take more chances and accept the way the media works. If they find their rescareh is being sensationalized or inaccuratcly reported, then hard luck ... just grin and bear it." Indeced, Wolfendale, who chaired a romnittee set up in 1995 to look at these: issues, has recently written a code of practice: to holp physicists doal with the median and the public. It advises scientists to siress the fact that they do not know everything and to emphasize that there are many problems ledi to solve.

Back in Cardiff, Harry Collins ahinks the answer lics with the way science is taught. "You only have to look at most physics textlomks and you'll sec crucial experiments being described as if they collapsed 50 ycars of confusion in one go. Science just doesn't work like that. We need the history of physics to be taught more sensibly. We need more pulitic education into how science works in practice, so that peopla aren't sur prised when they see scientists disagree and indeced that they expect uncertainty in the scientilic process" 